\title{
INTERSPECIFIC INTERACTIONS OF TREES WITH THE REGENERATION OF Ocotea odorifera (Vell.) Rohwer IN MIXED OMBROPHYLOUS FOREST
}

\author{
Cilmar Antônio Dalmaso ${ }^{1}$, Mario Takao Inoue ${ }^{2}$, Vânia Rossetto Marcelino ${ }^{2}$, Paulo Costa de Oliveira Filho ${ }^{2}$, \\ André Rosalvo Terra Nascimento ${ }^{4}$, Vinicius Costa Cysneiros ${ }^{1}$ \\ ${ }^{1}$ Federal University of Paraná, Post-Graduation Program in Forest Engineering, Curitiba, PR, Brazil - cilmard@ gmail.com; \\ vccysneiros.florestal@gmail.com \\ ${ }^{2}$ State University of the Midwest, Irati, PR, Brazil - martakino@gmail.com; vania@unicentro.br; paulocostafh@gmail.com \\ ${ }^{4}$ Federal University of Uberlândia, Umuarama Campus, Uberlândia, MG, Brazil - arnterra@gmail.com
}

Recebido para publicação: 04/10/2017 - Aceito para publicação: 09/08/2018

\begin{abstract}
This paper has the purpose to describe spatial interactions among predominant community tree species and seedlings and juveniles of Ocotea odorifera. The raised hypothesis is that some stablished species might attract or repulse Ocotea odorifera seedlings and juveniles in certain distances due to competition, allelopathy, resources sharing or other forms of mutualism or ecological processes. For acquiring spatial data and for floristic and structural characterization we used three nearby sampling units in the same Mixed Ombrophylous Forest (Araucaria Forest) patch. Each plot has 100 x 100 meters. We used the O-ring function $\left(\mathrm{O}_{12}\right)$, a null model for heterogeneous data, to the bivariate analysis and a test for the spatial independence hypothesis. All tested species presented a significant pattern, indicating that spatial interactions are frequent amongst mature and juvenile plants. Positive and negative interactions occurred in several scales and species. Although the significances were predominant in intervals up to 10 meters, where the negative interactions (repulsion or inhibition) were more frequent. For Araucaria angustifolia, a species that stood out in the community's horizontal structure, the negative interaction was present up to three meters. We found positive interactions in intervals from six to ten meters. The results showed strong inhibition of seedlings and juveniles by the same family species, suggesting that influences from negative spatial interaction, mainly from parental and with dominant community's species, may contribute to the processes and generating mechanisms of Ocotea odorifera spatial distribution in local scale.

Keywords: Brazilian sassafras, population ecology, spatial interactions, O-ring function $\left(\mathrm{O}_{12}\right)$.
\end{abstract}

\section{Resumo}

Interações interespecíficas de árvores com a regeneração de Ocotea odorifera (vell.) Rohwer em floresta ombrófila mista. Este trabalho teve o objetivo de descrever interações espaciais de espécies arbóreas predominantes na comunidade com indivíduos regenerantes de Ocotea odorifera. A hipótese levantada é que algumas espécies estabelecidas podem oferecer atração e/ou repulsão para as regenerantes de Ocotea odorifera em determinadas distâncias em função de competição, alelopatia, compartilhamento de recursos, entre outras formas de mutualismo ou processos ecológicos. Três áreas amostrais, no mesmo remanescente de Floresta Ombrófila Mista (Floresta com Araucária), com dimensões de 100 x 100 metros, foram amostradas para coleta de dados espaciais e caracterização estrutural e florística. Para realizar análises bivariadas e testar a hipótese de independência espacial foi utilizada a função O-ring $\left(O_{12}\right)$ com um modelo nulo para dados heterogêneos. Todas as espécies avaliadas apresentaram padrão significativo, indicando que as interações espaciais foram frequentes entre adultos e juvenis. Todas as espécies avaliadas apresentaram padrão significativo, indicando que as interações espaciais foram frequentes entre adultos e juvenis. No entanto, as significâncias ocorreram predominantemente nos intervalos de distâncias menores (até 10 metros), sendo mais frequentes, nessa escala, interações negativas, ou seja, de repulsão. Para Araucaria angustifolia, que se destacou na estrutura horizontal da comunidade, a interação negativa predominou até três metros, oferecendo logo em seguida no intervalo entre 6 e 10 metros uma dependência espacial positiva. Os resultados indicam forte inibição dos regenerantes com as árvores da própria família, sugerindo que as influências advindas da interação espacial negativa, principalmente com parentais e com as espécies dominantes na comunidade, contribuem nos processos e mecanismos geradores da distribuição espacial de Ocotea odorifera em escala local.

Palavras-chave: Canela-sassafrás; ecologia de populações; interações espaciais; função O-ring $\left(O_{12}\right)$. 


\section{INTRODUCTION}

The dynamics of a plant community is the shift of multispecies spatial patterns, driven by spatially dependent recruitment, mortality and growth processes, embedded in a heterogeneous landscape (LAW et al., 2009). In this context, basic information on interspecific interactions is fundamental to understanding ecological structures and coexistence of species in a community (LI et al., 2014) and may help reveal mechanisms of interspecific substitution, as well as providing a theoretical basis for restoration of vegetation (WANG et al., 2010, CHAI et al., 2016).

Understanding the coexistence of species is of particular relevance to plant communities in tropical rainforests, which are especially rich in species (BAGCHI et al., 2011). The dynamics of regeneration of tree species can be characterized by the scale of disturbances and environmental heterogeneity and the spatial relationship between adults and juveniles, and endogenous factors (vegetation structure and interactions between species) operate at different scales (GRAU, 2000). Spatial interactions may be negative, causing repulsion when there are fewer neighbors than expected for an independent distribution, or positive, causing attraction that manifests with densities of neighbors higher than expected. Negative spatial interaction may be the result of competition or allelopathy, giving that species with a stronger competitive capacity generally maintain more individuals in the offspring (DU et al., 2011). However, positive interactions are expected when there is a degree of beneficial interaction, such as mutualism or sharing of complementary resources (MAIHAITI; ZHANG, 2014, LUO et al., 2012).

Many processes can generate spatial patterns and one way to detect different types and scales of standards is the $O$-ring statistic, which provides a summary of the point-to-point distances (plant to plant), describing spatial dependence (second order characteristics) of the points (plants) in a mapped area (WIEGAND; MOLONEY, 2004). While first-order statistics describe the variation in intensity of plants in large-scale, second-order statistics summarize plant-to-plant distances, and in order to not confuse first order effects in the results it is necessary to consider the spatial heterogeneity of the possible underlying factors, and the null model must be carefully selected based on the ecological hypothesis adopted (WIEGAND; MOLONEY, 2004).

Spatial statistics have been little used in the face of the application potential, especially the bivariate functions and associated null models. The analysis using the bivariate $O$-ring function and the Poisson null model for heterogeneous data is a robust method with less significant results compared to the homogeneous function. However, the results allow a better estimate of the influence of second order factors. The possibility of generating a result with weighted average values for different samples also generates greater reliability of the results.

Brazilian Sassafras (Ocotea odorifera) is endemic to Brazil, with a discontinuous and irregular distribution, it has reproduction and dispersion factors that hinder its natural regeneration, was intensively exploited for commercial purposes and is currently considered to be in danger of extinction with special interest in conservation and management (CARVALHO, 2005). The ecological importance of brazilian sassafras makes it a species that demands more studies for application in its conservation. Studying the spatial patterns presented by this species in relation to the others is a way to better understand its ecology. The hypothesis raised in this study is that other established species may offer attraction and/or repulsion on the seedlings and juveniles of Ocotea odorifera under certain conditions and spatial scales. Thus, the objective was to answer the following questions: (1) interspecific interactions occur between adult trees of the dominant species with the natural regeneration of Ocotea odorifera? (2) the interspecific associations/interactions between adult trees and seedlings and juveniles of Ocotea odorifera, if confirmed, are predominantly positive, negative or is the spatial independence that prevails?

\section{MATERIAL AND METHODS}

\section{Area of study}

For this study, data were collected in 2011 in permanent plots installed in the Irati National Forest (FLONA), located in the south-central region of the State of Paraná at $25^{\circ} 20^{\prime} 24.818^{\prime \prime} \mathrm{S}$ and $50^{\circ} 33^{\prime} 44.889^{\prime \prime} \mathrm{W}$ and average altitude of $840 \mathrm{~m}$ (Figure 1). The region presents a predominant vegetation of Mixed Ombrophylous Forest, in which the Araucaria prints its own phyto-physiognomic aspect, due to its abundance, size and characteristic crown that emerges on the rest of the arboreal vegetation (GALVÃO et al., 1989). The climate in the region according to the Köppen classification system is of type Cfb: Subtropical Mesothermal Humid, with mild summers, severe and frequent frosts and without dry season.

Three sample areas (denominated blocks 1, 2 and 3 within a set of 25 hectares of permanent plots) were chosen, seeking to fulfill the premise of structural homogeneity, thus allocated on physiognomically similar surfaces and areas of one hectare (100 m X $100 \mathrm{~m})$ for each sample. 


\section{Collection of data}

The primary data with Cartesian coordinates, identification at the species level, total height (m) and DBH $(\mathrm{cm})$ of all trees with diameter at breast height $(\mathrm{DBH})$ greater than or equal to $10 \mathrm{~cm}$ (considered adult in this work) were provided by the UNICENTRO Forest Management Laboratory, which monitors the permanent plots (FIGUEIREDO FILHO et al., 2010). From the primary data the information of ten species with the highest number of individuals (considered dominant) in each block and of all species of the Lauraceae Family were extracted. Seedlings and juveniles individuals of Ocotea odorifera (with more than $30 \mathrm{~cm}$ of total height and DBH of less than $10 \mathrm{~cm}$ ) were measured following the same methodology used for the monitoring of permanent plots, except for seedlings with a diameter smaller than $3 \mathrm{~cm}$ or with a height less than 1.3 meters, which were only measured in regards to total height.

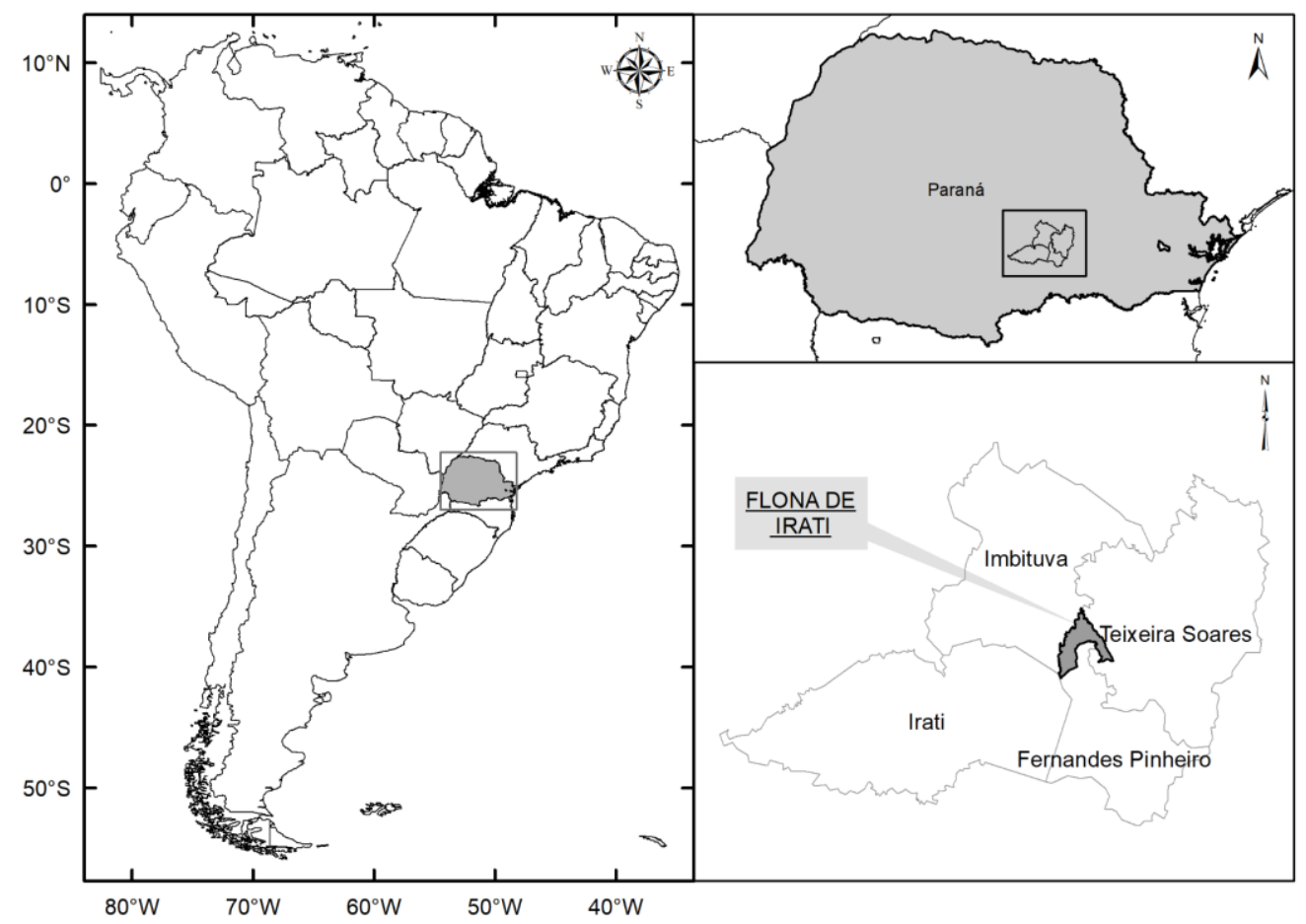

Figure 1. Geographic location of the National Forest of Irati (FLONA de Irati), between the municipalities of Fernandes Pinheiro, Imbituva, Irati and Teixeira Soares in the State of Paraná, Brazil.

Figura 1. Localização geográfica da FLONA (Floresta Nacional) de Irati, entre os municípios de Fernandes Pinheiro, Imbituva, Irati e Teixeira Soares no Estado do Paraná, Brasil.

\section{Statistical Methods and Analyzes}

For the analysis of spatial interactions, the bivariate function $O$-ring $\left(O_{12}\right)$ was used, which measures the expected density of points located at a certain distance from an arbitrary point in a space defined by a ring (a segment of a circle) (WIEGAND; MOLONEY, 2004). In this case, the $O$-ring $O_{12}$ (r) statistic was applied to measure the expected density of points of the "seedlings and juveniles individuals" class located at a distance $r$ from a point in the "adult trees" class. The null hypothesis was implemented as a heterogeneous Poisson process considering first order effects and thus testing the independence of the seedlings and juveniles distribution in relation to the adult trees of another species. The application of this function has the objective of avoiding effects of the environment, such as the spatial variability of the soil, and to ascertain results from the interaction between individuals (POTTKER et al., 2016). In this null model to test for independence, the locations of adult trees were fixed and the regenerating individuals of $O$. odorifera were randomly distributed with a non-constant intensity function. The variable intensity was constructed with the Kernel function and with a relatively small radius window $(30 \mathrm{~m})$. The null model (spatial independence hypothesis) generated confidence limits from 500 simulations to obtain $\alpha=0.01$ (DIGGLE, 2003).

In order to apply the spatial statistics function $O$-ring, the software Programita (WIEGAND; MOLONEY, 2004) was used. The calculation of the function involved the technical decision of the width of the "rings". In this work we sought to isolate classes from 3 meters away, counting that the density of regenerating individuals in the three study areas was high. The weighted average summary statistic for the three areas was calculated in order to show a single result. 
The spatial independence hypothesis was tested between seedlings and juveniles of Ocotea odorifera and adult trees of ten (10) dominant species and all adults of the Lauraceae Family, except the species O. odorifera itself. The species of lauraceae found were: Cinnamomum sellowianum (Nees \& Mart.) Kosterm., Nectandra grandiflora Nees, Nectandra megapotamica (Spreng.) Mez, Ocotea corymbosa (Meisn.) Mez, Ocotea diospyrifolia (Meisn.) Mez, Ocotea indecora (Schott) Mez, Ocotea porosa (Nees \& Mart.) Barroso and Ocotea puberula (Rich.) Nees. The analysis with all the congregated species of the Lauraceae Family was idealized due to the indications found in other studies (BAGCHI et al., 2011, LI et al., et al., 2014) that there is a tendency of the parental species (of the same taxonomic family) to present negative interaction. It was decided, then, to test if the same occurs in the present area of study. As the majority of the found species of Lauraceae did not occur in enough density for attainment of trustworthy individual results (statistical significant sample), it was opted to making the junction of them all in a test with the family.

\section{RESULTS}

\section{Characterization of structure of sample areas (adult trees)}

Floristic richness was 55 species in Block 1, 60 species in Block 2 and 52 species in Block 3. The basal area of each block was $27.38 \mathrm{~m}^{2} \cdot \mathrm{ha}^{-1}, 29.69 \mathrm{~m}^{2} \cdot \mathrm{ha}^{-1}$ and $31.41 \mathrm{~m}^{2} \cdot \mathrm{ha}^{-1}$ respectively. Ocotea odorifera had high relative density in the community $(15.98 \%, 18.43 \%$ and $34.31 \%$, respectively for Block 1, Block 2 and Block 3$)$, and also stood out with $9.42 \%, 12.12 \%$ and $24.77 \%$ of the basal area (relative dominance) in Block $1\left(2.58 \mathrm{~m}^{2}\right)$, Block $2\left(3.60 \mathrm{~m}^{2}\right)$ and Block $3\left(7.78 \mathrm{~m}^{2}\right)$, respectively. In the three areas of this study Ocotea odorifera presented a high cover value (phytosociological data of FIGUEIREDO FILHO et al., 2010) due to the choice of areas with higher density of the species, being therefore cautious to generalize these estimates due to non-randomness in the choice of samples.

The distributions of the diameters for each of the study areas are shown in Figure 2. It is possible to observe, by analyzing the graphs, that the three areas accumulate a large number of individuals in the classes of smaller diameters, as is characteristic of tropical and subtropical forests, in which the frequency in the classes are distributed in an inverted $\mathbf{J}$ or negative exponential $\mathbf{J}$ histogram.

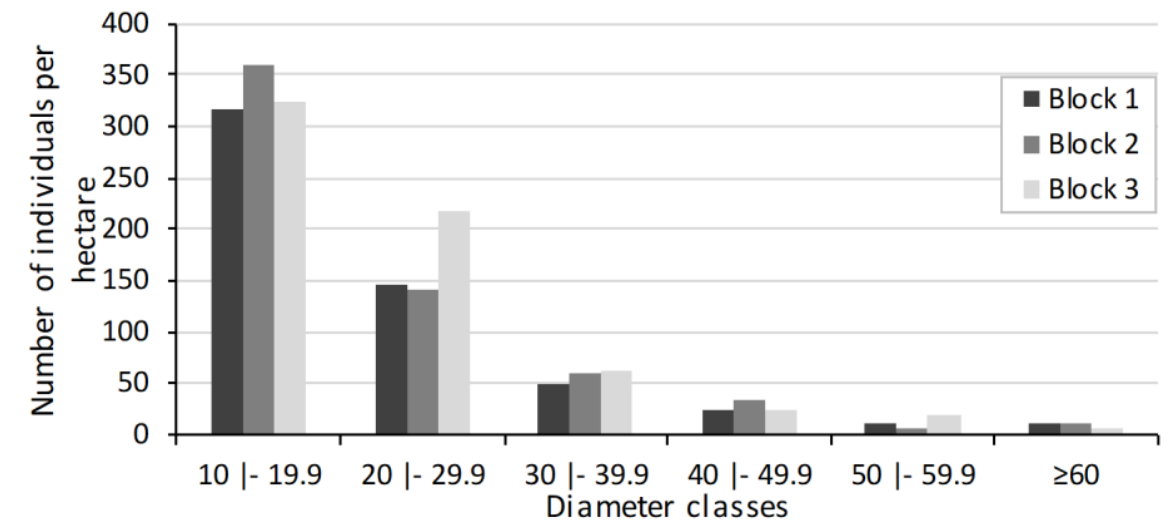

Figure 2. Diametric distribution of study areas in National Forest of Irati, PR, Brazil.

Figura 2. Distribuição diamétrica das áreas de estudo na FLONA de Irati, PR.

The number of adult individuals from the ten dominant species selected for the analyzes, in addition to those belonging to the Lauraceae Family and the number of seedlings and juveniles of O.odorifera, can be visualized in Table 1.

Table 1. Number of individuals $(\mathrm{N})$ of the species analyzed in each block in National Forest of Irati, PR, Brazil. Tabela 1. Número de indivíduos $(\mathrm{N})$ das espécies analisadas em cada bloco na FLONA de Irati, PR.

\begin{tabular}{cccccc}
\hline \multirow{2}{*}{ Abrev. of the species } & Species & \multirow{2}{*}{ Block 1 } & Block 2 & \multirow{2}{*}{ Block 3 } & \multirow{2}{*}{ Total } \\
\cline { 2 - 5 } & & $\mathbf{N}$ & $\mathbf{N}$ & $\mathbf{N}$ & \\
\hline Arau & Araucaria angustifolia (Bertol.) Kuntze & 25 & 24 & 31 & 80 \\
Case & Casearia decandra Jacq. & 35 & 29 & 35 & 99 \\
Cass & Casearia sylvestris Sw. & 22 & 9 & 50 & 81 \\
Cedr & Cedrela fissilis Vell. & 6 & 25 & 10 & 41
\end{tabular}




\begin{tabular}{cccccc}
\hline \multirow{2}{*}{ Abrev. of the species } & Species & \multirow{2}{*}{ Block 1 } & \multirow{2}{*}{ Block 2 } & \multirow{2}{*}{ Block 3 } & \multirow{2}{*}{ Total } \\
\cline { 2 - 5 } & & $\mathbf{N}$ & $\mathbf{N}$ & $\mathbf{N}$ & \\
\hline Cous & Coussarea contracta (Walp.) Müll. Arg. & 35 & 22 & 21 & 78 \\
Dalb & Dalbergia brasiliensis Vogel & 8 & 28 & 9 & 45 \\
Ilex & Ilex paraguariensis A.St.-Hil. & 33 & 31 & 42 & 106 \\
Myrc & Myrcia hebepetala DC. & 20 & 17 & 16 & 53 \\
Myrt & Myrcia tomentosa (Aubl.) DC. & 7 & 22 & 12 & 41 \\
Nect & Nectandra grandiflora Nees & 8 & 30 & 21 & 59 \\
Laur & Lauraceae (except O.odorifera) * & 67 & 83 & 61 & 211 \\
Seedling & Seedlings and juveniles of O. odorifera & $\mathbf{2 8 4 3}$ & $\mathbf{7 5 8}$ & $\mathbf{1 5 2 6}$ & $\mathbf{5 1 2 7}$ \\
\hline
\end{tabular}

* Including species: Cinnamomum sellowianum (Nees \& Mart.) Kosterm., Nectandra grandiflora Nees, Nectandra megapotamica (Spreng.) Mez, Ocotea corymbosa (Meisn.) Mez, Ocotea diospyrifolia (Meisn.) Mez, Ocotea indecora (Schott) Mez, Ocotea porosa (Nees \& Mart.) Barroso and Ocotea puberula (Rich.) Nees.

\section{Interspecific spatial interactions}

In Figure 3 there are the graphic results of the analysis $O_{12}$ between the seedlings and juveniles individuals of Ocotea odorifera and the adult trees of Araucaria angustifolia (Figure 3 A), Casearia decandra (Figure 3 B), Ilex paraguariensis (Figure 3 C), Casearia sylvestris (Figure 3 D), Cedrela fissilis (Figure 3 E), Myrcia hebepetala (Figure $3 \mathrm{~F}$ ), Coussarea contracta (Figure $3 \mathrm{G}$ ), Dalbergia brasiliensis (Figure $3 \mathrm{H}$ ), Myrcia tomentosa (Figure 3 I), Nectandra grandiflora (Figure $3 \mathrm{~J}$ ) and Lauraceae (except the O. odorifera) (Figure $3 \mathrm{~K}$ ). When the empirical value of $O_{12}$ (dark line) appears negative, exceeding the lower confidence limit, it means that the pattern (between the two species) is of repulsion, and when $O_{12}$ is positive, exceeding the upper confidence limit, that indicates that the pattern is of attraction, otherwise the species exhibit independence.
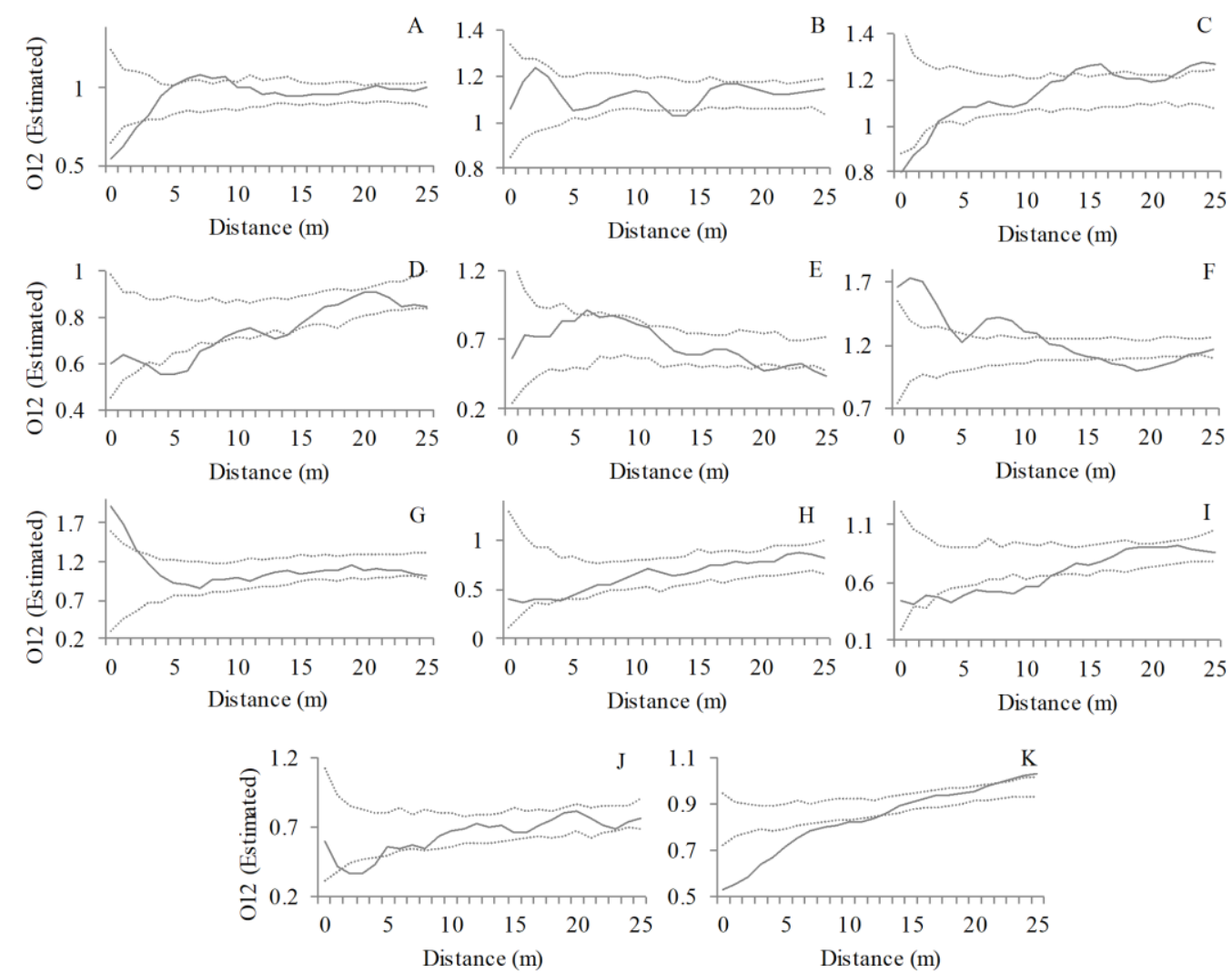

Figure 3. Analysis of spatial dependency with a function $O_{12}$ between the seedlings and juveniles of Ocotea odorifera and the adults trees of Araucaria angustifolia (A), Casearia decandra (B), Ilex paraguariensis (C), Casearia sylvestris (D), Cedrela fissilis (E), Myrcia hebepetala (F), Coussarea contracta (G), Dalbergia brasiliensis (H), Myrcia tomentosa (I), Nectandra grandiflora (J) and Lauraceae (except O.odorifera) (K). 
Figura 3. Análise de dependência espacial com a função $O_{12}$ entre regenerantes de Ocotea odorifera e as árvores adultas de Araucaria angustifolia (A), Casearia decandra (B), Ilex paraguariensis (C), Casearia sylvestris (D), Cedrela fissilis (E), Myrcia hebepetala (F), Coussarea contracta (G), Dalbergia brasiliensis (H), Myrcia tomentosa (I), Nectandra grandiflora (J) e Lauraceae (exceto O.odorifera) (K).

At close scales (up to 10 meters), negative interactions were more frequent (Araucaria angustifolia, Casearia sylvestris, Dalbergia brasiliensis, Ilex paraguariensis, Myrcia tomentosa, Nectandra grandiflora and Lauraceae). Species Coussarea contracta and Myrcia hebepetala showed a tendency of attracting juvenile individuals from Ocotea odorifera. Araucaria angustifolia showed a tendency of repulsion in the first 3 meters and then in the scale of 6 to 9 meters presented an inverse behavior. Casearia decandra and Casearia sylvestris showed similar trends in the scale close to 15 meters, both with significant negative interactions. Nectandra grandiflora (Figure $2 \mathrm{~J}$ ) and all other Lauraceae (Figure $2 \mathrm{~K}$ ) showed significant negative spatial interactions, reinforcing the hypothesis of interspecific competition with the adult trees of the family.

In Table 2, the significant results of interactions for each species in the scales of up to 25 meters can be observed. From the general total it is possible to visualize the species (column) and the scales (in the lines) in which there were more frequent significant interactions and to discriminate the positive or attraction interactions $(+)$ and the negative or repulsion interactions (-).

Table 2. Significance of the bivariate analysis with $O_{12}$ function in the different scales analyzed for each species in relation to the seedlings and juveniles of $O$. odorifera.

Tabela 2. Significância da análise bivariada com a função $O_{12}$ nas diferentes escalas analisadas para cada espécie em relação às regenerantes de $O$. odorifera.

\begin{tabular}{|c|c|c|c|c|c|c|c|c|c|c|c|c|}
\hline Scale & Arau & Case & Cass & Cedr & Cous & Dalb & Ilex & Myrc & Myrt & Nectg & Laur & Total \\
\hline 1 & - & & & & + & & - & + & & & - & 5 \\
\hline 2 & - & & & & + & & - & + & & & - & 5 \\
\hline 3 & - & & & & + & & - & + & & - & - & 6 \\
\hline 4 & & & - & & & & & + & - & - & - & 5 \\
\hline 5 & & & - & & & - & & + & - & - & - & 6 \\
\hline 6 & + & & - & & & & & & - & & - & 4 \\
\hline 7 & + & & - & + & & & & + & - & & - & 6 \\
\hline 8 & + & & - & & & & & + & - & & - & 5 \\
\hline 9 & + & & - & & & & & + & - & & - & 5 \\
\hline 10 & + & & & & & & & + & - & & - & 4 \\
\hline 11 & & & & & & & & + & - & & - & 3 \\
\hline 12 & & & & & & & & + & - & & - & 3 \\
\hline 13 & & & & & & & & & - & & - & 2 \\
\hline 14 & & - & - & & & & & & & & & 2 \\
\hline 15 & & - & - & & & & + & & & & & 3 \\
\hline 16 & & & & & & & + & & & & & 1 \\
\hline 17 & & & & & & & + & - & & & & 2 \\
\hline 18 & & & & & & & & - & & & & 1 \\
\hline 19 & & & & & & & & - & & & & 1 \\
\hline 20 & & & & & & & & - & & & & 1 \\
\hline 21 & & & & - & & & & - & & & & 2 \\
\hline 22 & & & & - & & & & - & & & & 2 \\
\hline 23 & & & & & & & + & - & & & + & 3 \\
\hline 24 & & & & & & & + & & & & + & 2 \\
\hline 25 & & & & - & & & + & & & & + & 3 \\
\hline Total & 8 & 2 & 8 & 4 & 3 & 1 & 9 & 18 & 10 & 3 & 16 & \\
\hline
\end{tabular}

\section{DISCUSSION}

The study area, which is a natural forest with at least 50 years without large-scale disturbances, presented a tree community in good condition, with a representative number of individuals and species per unit área. The horizontal structure has a distribution of diameters and phytosociological estimators, characteristic of selfregeneration communities of Mixed Ombrophylous Forest (FIGUEIREDO FILHO et al., 2010). 
Ocotea odorifera is an endangered species that predominates in the study area and has been preliminarily investigated as to the spatial distribution of adult and juvenile individuals (POTTKER et al., 2016; DALMASO et al., 2013) and intraspecific interactions between size classes (DALMASO et al., 2016). The species showed ability to maintain dominance in the area by the large number of representatives in the various size classes. The results indicate that grouped spatial patterns predominate for juvenile individuals with a tendency to randomness in the adult phase, although clusters of adult individuals may occur over longer distances. Negative spatial interactions between size classes of juvenile plants with possible parent trees were frequent, especially at distances up to five meters, while positive interactions were detected only among regenerating individuals. Although spotting is clear for Ocotea odorifera, the community has a multi-species structure in which interspecific interactions can be frequent and possible to be investigated.

Luo et al. (2012) cites that the majority of the tropical and subtropical forests is rich in species, what generally means decreases densities of individuals, resulting in weakness of the interspecific interactions, and the positive associations are still more rare (KUBOTA et al., 2007; MARTINEZ et al., 2010). On the other hand, Bagchi et al. (2011) found evidence that competition prevails among $40 \%$ of tropical species, while approximately $10 \%$ of species are affected by facilitation processes. Volkov et al. (2009) studied the interactions among the 20 main species in 50 hectares of tropical forest were studied, where they observed that the effects of interactions between interspecific pairs are relatively weak compared to intraspecific interactions, in this case, in a larger spatial scale.

In this work it was verified that $O$. odorifera seedlings and juveniles present spatial dependence with adult trees of arboreal species in a diversity of scales according to each species. All species evaluated presented a significant pattern by overcoming the confidence interval at some distance, indicating that spatial interactions are frequent among adults and young individuals of $O$. odorifera. Generally the significance occurs in the near distance intervals (up to $10 \mathrm{~m}$ ), that is, the closer the adult and juvenile trees to O. odorifera, the greater the probability of spatial interactions. The results suggest that the influence of negative spatial interaction mainly with parental (Lauraceae) and with the dominant species in the community (Araucaria angustifolia) in addition to Ilex paraguariensis, contributes to the processes and mechanisms that generates the spatial distribution of $O$. odorifera on a local scale. Such species occur with high frequency, intensifying the repulsive pattern. Araucaria angustifolia presented signs of competitive behavior with the regeneration of $O$. odorifera in a first space (on a scale of 1 to 3 meters), and in a second space (on the 6 to 10 meter scale) the positive interaction prevailed as a mechanism that delays or prevents competitive exclusion. Some inferences are formulated, as the thicker layer of litter under the canopy of Araucaria angustifolia (common due to the slow decomposition of conifer material) is a physical impediment to the seeds of $O$. odorifera, which lose viability, or some allelopathic effect of the root zone near the stem. Luo et al. (2012) studied spatial interactions of tree species in a subtropical hardwood forest and found that positive associations are more prevalent than negative associations, especially among pairs of species with similar habitat preferences or similar requirements to establish.

Diggle (2003) suggested that small scale effects are attributed to second order plant-to-plant interactions and large scale effects are attributed to environmental heterogeneity. Ocotea odorifera is a shadow-tolerant species in the early stages and Araucaria angustifolia produces a dense and broad crown that can modify the surrounding environment and favor regeneration. In the vicinity of the crown projection area there should be the greatest shading for most of the day and year depending on the latitude of the study area. Bett and May (2017) observed an increase in the number of juveniles as the distance from the central trunk increased and found a significant correlation between the amount of litter and the number of regenerating individuals. The same authors observed that the plots with the highest number of seedlings were not influenced by luminosity. In this context, we can infer that a possible absence of the Araucaria angustifolia species, also threatened with extinction, could alter the natural distribution pattern of $O$. odorifera on a local scale. These and other questions reflect the importance of the conservation of the forest remainders.

Except close to Araucaria angustifolia, Ilex paraguariensis and Lauraceae, all the too much analyzed species tend to facilitate the conscription of $O$. odorifera, mainly Coussarea contracta and Myrcia hebepetala, that they had presented evidences of an attraction behavior/facilitation with the seedlings and juveniles. The prevalence of absence of significant interactions in next distances is waited when the species explore different niches. Lan et al. (2012) studied the space patterns of the arboreal species of a Tropical Forest Sazonal in China, in which $42.6 \%$ of all the combinations of pairs of species with the seedlings had presented positive associations in scales of neighborhood of up to five meters, and only $38.4 \%$ had been negative. For Luo et al. (2012), attractions of small scale, which allows that the species explore a parcel bigger of the available resources, deeply influences the structure of the community. According to references (LORENZI, 1998, CARVALHO, 1980; 2003) on the fruiting period, species that presented positive interaction at close scales overlap, at least in part, the same fruiting period, being $O$. odorifera in the period from April to June, Coussarea contracta in a shorter period, between April and May and Myrcia hebepetala in a longer period, from May to August. Due to the fleshy characteristic of these

FLORESTA, Curitiba, PR, v. 49, n. 2, p. 189-198, abr/jun 2019. 
fruits (drupe and berry type), they attract mainly birds, probably sharing the same dispersers, being so that $O$. odorifera stands out for its high frequency and fruit production. If there is a sharing of resources by the supply of complementary foods, the species benefit and this can be considered a facilitation process.

Ocotea odorifera presents dispersion by animals (zoocory), and the groups of animals cited as responsible for this process are mainly birds, primates and rodents (CARVALHO, 2005). This factor may be important due to the high production of fruits that these species present (personal observation), together with the high frequency in the community, that is to say, the three species together. O. odorifera, Coussarea contracta and Myrcia hebepetala tends to benefit. Interspecific interaction is associated with evolution, when species seek to maximize benefit with their "neighbors," while minimizing cost and risk driven by negative interactions (Mahihati and Zhuang, 2014). For tropical trees, partial overlap and segregation increase with spatial scale, where species with the same habitat preference tend to associate more frequently on small scales (LUO et al., 2012), suggesting that these species possess the same preference for microhabitats. Positive interspecific interactions among plant species can also occur when two species compete strongly for phenotypes and patterns of use of similar resources (MAIHAITI; ZHANG, 2014). Another possibility is that the species that had presented attraction with Ocotea odorifera had been dependents ones of the others during the long period of co-evolution (MAIHAITI; ZHANG, 2014).

The most significant negative values found in this study were offered by Lauraceae Family individuals, and suggest stronger interspecific family interactions. The results of the independence test of the adult trees of the family with the seedlings and juveniles of $O$. odorifera (Figure $2 \mathrm{~K}$ ) presented the line of empirical values with a linear configuration indicating negative effects at close distances up to 13 meters, spatial randomness of 14 to 22 meters and a trend of positive interactions at distances greater than 23 meters. In the distance of 23 to 25 meters, from any adult tree of the Lauraceae Family, there is a greater probability of seedlings and juveniles clusters occurring. Li et al. (2014) studied interactions of similar types in subtropical forest and observed that the individuals that share many phenotypic characteristics and ecological fellow creatures tend to use a set of resources in similar way, being able to present competition. The negative interaction with parental is waited as resulted of the known process as Negative Density Dependence (NDD), that it affects the survival of trees in areas of high density of conspecifics due to the increase of the attack for natural enemies (BAGCHI et al., 2011). Thus, the present study adds, with the literature, indications that individuals of the same botanical family tend to present a process of repulsion.

\section{CONCLUSIONS}

- Spatial interactions are frequent among adult trees of dominant species with Ocotea odorifera juveniles, mainly at the nearest distances intervals. However, the prevalence of absence of interactions, in addition to positive interactions from $10 \mathrm{~m}$ distance, indicates that Ocotea odorifera has a good adaptation/"acceptance" by the other species in the community. This fact evidences the ease of the conservationist management of brazilian sassafras, at least in the sense that it does not need detailed care in the selection of the species that come to live with it in a process of ecosystem restoration, provided that the minimum distances between individuals are respected.

- Influences arising from spatial interaction with some species contribute to the processes and mechanisms that generate the spatial distribution of Ocotea odorifera on a local scale, and often a negative pattern is offset by a positive one or vice versa on a different scale. The results can be associates the different mechanisms of dispersion and establishment and/or to the proportionate microenvironment for some species.

- Evidence of inhibition of seedlings and juveniles with family trees (Lauraceae) on a smaller scale; evidences that seedlings and juveniles of Ocotea odorifera are more frequent in the (external) environment of the crown area of Araucaria angustifolia and evidence of attraction on a smaller scale (as occurred between Coussarea contracta and Myrcia hebepetala with seedlings and juveniles of Ocotea odorifera) allow to generate new hypotheses about ecological processes like competition, dispersion, increase of the attack by natural enemies, among others.

\section{ACKNOWLEDGMENTS}

To the Graduate Program in Forestry Sciences and to the Forestry Engineering Department of UNICENTRO, for the opportunity and support to make this study possible. Professor Afonso Figueiredo Filho and other collaborators of the Forest Management Laboratory, for making available the primary data used in this study. To CAPES, for the scholarship granted to the first author. To the Chico Mendes Institute of Biodiversity 
Conservation (ICMBio), for the authorization granted ( $\left.\mathrm{n}^{\mathrm{o}} 25871-1\right)$ for the activities in the FLONA of Irati. To all who assisted in the field data collection.

\section{REFERENCES}

BAGCHI, R .; HENRYS, PA; BROWN, PE; BURSLEM，DFRP; DIGGLE，PJ; GUNATILLEKE，CVS; GUNATILLEKE, IAUN; KASSIM, AR; LAW, R .; NOOR, S .; VALENCIA, RL Spatial patterns reveal negative density dependence and habitat association in tropical trees. Ecology, Washington, v. 92, n. 9, p. 1723-1729, 2011.

BETT, LA; MAY, D. Natural regeneration of Ocotea odorifera (Vell.) Rohwer (Lauraceae) in Mixed Ombrophilous Forest, Paraná, Brazil. Forest Science, Santa Maria, v. 27, n. 2, p. 707-717, 2017.

CARVALHO, PER Floristic survey of the region of Irati - PR (First approximation). Curitiba, PR. EMBRAPA / Regional Center for Forestry Research Centro Sul, 1980, 44 p. (Technical Circular, 3).

CARVALHO, PER Brazilian Arboreal Species. Collection Arboreal Brazilian Species, vol. 1. Brasília: Embrapa Information Technology; Colombo, PR: Embrapa Florestas, 2003. 1,039 p.

CARVALHO, PER Brazilian sassafrás. Technical Circular, 110. Colombo: EMBRAPA Forests, 2005. 12 p.

CHAI, Z .; SUN, C .; WANG, D .; LIU, W. Interspecific associations of dominant tree populations in a virgin oldgrowth oak forest in the Qinling Mountains, China. Botanical Studies, London, v. 57, n. 23, p. 1-13, 2016.

DALMASO, CA; INOUE, MT; FILHO, PC DE O .; MARCELINO, VR Spatial patterns in the regeneration of Ocotea odorifera in the Irati National Forest, PR. Forest, Curitiba, v. 43, n. 2, p. 301-312, 2013.

DALMASO, CA; INOUE, MT; MARCELINO, VR; DE OLIVEIRA FILHO, PC Intraspecific spatial interactions of Ocotea odorifera in the Irati National Forest. Forest, Curitiba, v. 46, n. 1, p. 103-114, 2016.

DIGGLE, PJ Statistical analysis of spatial point patterns. London: Edward Arnold, 2 ed. 2003, 159 p.

DU, X .; ZHOU, S .; ETIENNE, RD Negative density dependence on the effect of species competitive asymmetry: a niche-based mechanism for neutral-like patterns. Journal of Theoretical Biology, Amsterdam, v.278, p. 127$134,2011$.

FIGUEIREDO FILHO, A .; DIAS, AN; STEPKA, TF; SAWCZUK, AR Growth, mortality, ingress and diametric distribution in Mixed Ombrophilous Forest. Forest, v. 40, n. 4, p. 763-776, 2010.

GALVÃO, F .; KUNIYOSHI, YS; RODERJAN, CV Phytosociological survey of the main arboreal associations of the Irati National Forest - PR. Forest, Curitiba, v.19, p. 30-49, 1989.

GRAU, HR Regeneration patterns of Cedrela lilloi (Meliaceae) in northwestern Argentina subtropical montane forests. Journal of Tropical Ecology, New York, v. 16, p. 227-242, 2000.

KUBOTA, Y .; KUBO, H .; SHIMATANI, K. Spatial pattern dynamics over 10 years in a conifer / broadleaved forest, northern Japan. Plant Ecology, London, v. 190, n.1, p. 143-157, 2007.

LAN, G .; GETZIN, S .; WIEGAND, T .; HU, Y .; XIE, G .; ZHU, H .; CAO, M. Spatial distribution and interspecific associations of tree species in a tropical seasonal rain forest of China. PLoS ONE, San Francisco, v. 7, n. 9, p. 46074-46080, 2012.

LAW, R .; ILLIAN, J .; BURSLEM, DFRP; GRATZER, G .; GUNATILLEKE, CVS; GUNATILLEKE, IAUN Ecological information from spatial patterns of plants: insights from point process theory. Journal of Ecology, London, v. 97, p. 616-628, 2009.

LI, L .; YE, WH; WEI, SG; LIAN, JY; HUANG, ZL Spatial patterns and associations between species belonging to four genera of the Lauraceae Family. PLoS ONE, San Francisco, v. 9, n. 11, p. 1-11, 2014.

LORENZI, H. Brazilian trees: manual of identification and cultivation of native tree plants of Brazil. 2. Ed. Nova Odessa, SP: publisher Plantarum, 1998. 352 p.

LUO, ZR; YU, MJ; CHEN, DL; WU, YG; DING, BY Spatial associations of tree species in a subtropical evergreen broad-leaved forest. Journal of Plant Ecology, Oxford, v. 5, n. 3, p. 346-355, 2012.

MAIHAITI, M ; ZHANG, WJ A mini review on theories and measures of interspecific associations. Selforganizology, Guangzhou, v. 1, p. 206-210, 2014. 
MARTINEZ, I .; WIEGAND, T .; GONZALEZ-TABOADA, F .; OBESO, JR Spatial associations among tree species in a temperate forest community in north-western Spain. Forest Ecology Management, Amsterdam, v. 260, n. 4, p. 456-465, 2010.

POTTKER, GS; OLIVEIRA FILHO, PC; FIGUEIREDO FILHO, A .; DALMASO, CA Spatial pattern of forest species: case study with Ocotea odorifera (Vell.) Rohwer. Forest Science, Santa Maria, v. 24, n. 4, p. 1097-1106, 2016

VOLKOV, I .; BANAVAR, JR; HUBBELL, SP; MARITAN, A. Inferring species interactions in tropical forests. Proceedings of the National Academy of Sciences, Washington, v. 106, n. 33, p. 13854-13859, 2009.

WANG, XG; WIEGAND, T .; HAO, ZQ; LI, BH; YE, J .; LIN, F. Species associations in an old-growth temperate forest in north-eastern China. Journal of Ecology, London, v. 98, p. 674-686, 2010.

WIEGAND, T ; MOLONEY, KA Rings, circles, and null-models for point pattern analysis in ecology. Ecography, Lund, v. 104, n.2, p. 109-229, 2004. 